\title{
Open Spaces and Human Interaction
}

\author{
Dasimah Omara, Filzani Illia Ibrahimb ${ }^{b}$ Nik Hanita Nik Mohamadc \\ aCentre of Studies for Town and Regional Planning, \\ ${ }^{b}$ Centre of Postgraduate Studies, ${ }^{\circ}$ Centre of Studies for Landscape Architecture, \\ Faculty of Architecture, Planning \& Surveying, Universiti Teknologi Mara (UiTM) \\ dasimah629@salam.uitm.edu.my
}

\begin{abstract}
There are various studies on how open spaces provide a positive reaction to human. Apparently, in relation to open spaces, Malaysia has received very little attention from researchers. The objective of this paper is to provide valuable insights into how human interact with outdoor urban environments. The analysis in this study will address human-human interaction and human-nature interaction in the open spaces at Taman Tasik Shah Alam in Selangor, Malaysia. The findings of this study will show the main domains of interaction towards open spaces together with the perceived benefits to the open spaces users.
\end{abstract}

Keywords: Open Spaces; Physical Health, Outdoor Urban Environment; Human Interaction

eISSN: 2398-4295 @ 2017. The Authors. Published for AMER ABRA by e-International Publishing House, Ltd., UK. This is an open access article under the CC BY-NC-ND license (http://creativecommons.org/licenses/by-ncnd/4.0/). Peer-review under responsibility of AMER (Association of Malaysian Environment-Behaviour Researchers), ABRA (Association of Behavioural Researchers on Asians) and cE-Bs (Centre for EnvironmentBehaviour Studies), Faculty of Architecture, Planning \& Surveying, Universiti Teknologi MARA, Malaysia.

http://dx.doi.org/10.21834/ajbes.v2i6.36 


\subsection{Introduction}

Open spaces can be seen as among vital social infrastructure that is required in any housing development. It plays an important role in improving environmental ecosystem (Marzukhi, Karim, \& Latfi, 2012). The major function of open space is to satisfy people's recreational need (Chiesura, 2004).Arifin (2005) claimed that open spaces with its plant represents as a green open space that act as production for the oxygen, controlling the surrounding ecosystem and controlling the soil water. Moreover, open spaces also take the role as a buffer towards sounds, wind, dust and the sun. But the truth is the designer will plan the open spaces based on real or perceived notions of recreation needs. The three important devices according to Philips (1996) in measuring the successfulness of open spaces are good design, proper management and supportive people. Apart from that, open spaces are positive elements of our urban environment and landscape. Properly designed open spaces are an asset to the entire city (Philips, 1996).

According to Federal Department of Town and Country Planning of Peninsular Malaysia (2004) open space means any land whether enclosed or not which is laid out or reserved for laying out wholly or partly as a public garden, park, sports and recreation ground, pleasure ground, walk or as a public place.Chiesura (2004), defined open space as a space that is exposed to the environment or external factors by means of a nature orientated outdoor recreation and trail-related activities and can be divided into two which are public open space and private open space. Public open space is for the public enjoyment whereby the private open space is to fulfil certain group of society.

\section{0 Literature Review}

People's relationship with the open spaces is different based on some factors such as socio-economic, gender, type of activities and park facilities. According to Mutiara \& Isami, (2012) people's involvement and interaction in the open spaces can enhance the sense of belonging to people and at the same time increase the degree of neighbourhood attachment. According to Matsuoka \& Kaplan, (2008), they provide a valuable insights into how human interact with outdoor urban environments, which included open spaces itself. Thus, they come out with major themes that are directly linked to the open spaces that are the human-nature interaction and human-human interaction. As for the human needs, the variables to be measured are social interaction, citizen participation, and a sense of community as shown in Table 1.

Table 1: Theoretical Framework of Human Interaction in Open Spaces (Matsuoka \& Kaplan, 2008)

\begin{tabular}{|l|l|l|l|l|l|l|l|}
\hline Author & \multicolumn{2}{|l|}{ Nature needs } & \multicolumn{2}{l|}{ Human needs } & $\begin{array}{l}\text { Primary } \\
\text { Data }\end{array}$ \\
\hline & $\begin{array}{l}\text { Contact } \\
\text { with } \\
\text { nature }\end{array}$ & $\begin{array}{l}\text { Aesthetic } \\
\text { Preference }\end{array}$ & $\begin{array}{l}\text { Recreation/ } \\
\text { play }\end{array}$ & $\begin{array}{l}\text { Social } \\
\text { interaction } \\
\text { / privacy }\end{array}$ & $\begin{array}{l}\text { Citizen } \\
\text { Partici } \\
\text { pation }\end{array}$ & $\begin{array}{l}\text { Sense of } \\
\text { Community }\end{array}$ & $\begin{array}{l}\text { Quantitative } \\
\text { /Qualitative } \\
\text { Data }\end{array}$ \\
\hline
\end{tabular}


Omar, D., et.al. / Asian Journal of Behavioural Studies, AjBeS, Apr / Jun 2017 (p.37-46)

\begin{tabular}{|c|c|c|c|c|c|c|c|}
\hline Austin (2004) & $\bullet$ & & & $\bullet$ & & $\bullet$ & Qualitative \\
\hline $\begin{array}{l}\text { Chiesura } \\
\text { (2004) }\end{array}$ & $\bullet$ & & $\bullet$ & $\bullet$ & $\bullet$ & & Quantitative \\
\hline Gobster (2001) & $\bullet$ & $\bullet$ & $\bullet$ & & $\bullet$ & $\bullet$ & Both \\
\hline Oguz (2000) & $\bullet$ & $\bullet$ & $\bullet$ & $\bullet$ & & & Qualitative \\
\hline $\begin{array}{l}\text { Ozguner and } \\
\text { Kendle (2006) }\end{array}$ & $\bullet$ & $\bullet$ & & $\bullet$ & & & Quantitative \\
\hline $\begin{array}{l}\text { Abu-Ghazzeh } \\
\text { (1996) }\end{array}$ & $\bullet$ & & & & • & $\bullet$ & Qualitative \\
\hline $\begin{array}{l}\text { Crow et.al } \\
(2006)\end{array}$ & $\bullet$ & $\bullet$ & $\bullet$ & $\bullet$ & & & Quantitative \\
\hline $\begin{array}{l}\text { Dokmeci and } \\
\text { Berkoz }(2000)\end{array}$ & $\bullet$ & $\bullet$ & & $\bullet$ & & & Quantitative \\
\hline $\begin{array}{l}\text { Hull et.al } \\
(1994)\end{array}$ & $\bullet$ & & & & & $\bullet$ & Qualitative \\
\hline $\begin{array}{l}\text { Lucy and } \\
\text { Phillips (1997) }\end{array}$ & $\bullet$ & & & & & $\bullet$ & Qualitative \\
\hline $\begin{array}{l}\text { Vogt and } \\
\text { Marans (2004) }\end{array}$ & $\bullet$ & $\bullet$ & $\bullet$ & $\bullet$ & & & Qualitative \\
\hline $\begin{array}{l}\text { Herrington } \\
\text { \&Studtman } \\
\text { (1998) }\end{array}$ & $\bullet$ & & & $\bullet$ & & & Qualitative \\
\hline $\begin{array}{l}\text { Coles and } \\
\text { Bussey }(2000)\end{array}$ & $\bullet$ & & & $\bullet$ & $\bullet$ & & Both \\
\hline Simson (2000) & $\bullet$ & $\bullet$ & & & & $\bullet$ & Qualitative \\
\hline $\begin{array}{l}\text { Yuen and Hien } \\
(2005)\end{array}$ & $\bullet$ & $\bullet$ & $\bullet$ & $\bullet$ & & & Qualitative \\
\hline
\end{tabular}

\subsection{Issues On Human Interaction}

According to Rasidi, Jamirsah, \& Said (2012), there is an increasing trend of research regarding on significance of open spaces. The growing scarcity of open space is at concern of local authorities nowadays since there are not much of quality open spaces areas left.

Malaysia is developing towards' urban and suburban landscapes, hence maintaining quality of open spaces needs a vital attention in ensuring open spaces are fully utilized, and the users are interact towards the nature or human (Rasidi et al., 2012). Issues investigated concern the human interaction for open spaces, the emotional component involved in their experienced of nature and the benefits perceived.

\subsection{Methodology}

\subsection{Variables Measured}

This research explores human interactions in open spaces and the perceived benefits from the interactions towards the area. The unit of analysis is the various range of age group of the open spaces in Shah Alam Lake Garden, Selangor, Malaysia. The approach in dividing the variables into two major categories were for collecting data systematically and to see how daily usage pattern of open spaces was related to the interactions (Rasidi et al., 2012). 


\subsection{Methods}

A total of 500 of survey questionnaires were distributed within the study area. However, only 427 reliable respondents were taken for further analysis due to the other 73 respondents left the questionnaires blank. Respondents were provided with a survey form with few subsections to determine their level of background, such as gender, income, companionship, mode of transportation to the open spaces, frequency of visits and time spend per visits. The respondents also were asked their main purposes of coming to the open spaces that are can be divided into two sub-sections that are human-nature interaction or human-human interaction.

\subsection{Study Area}

The selected study area for the study is Shah Alam Lake Garden, which serves as the urban park. It functions as one of the favorite retreat of the residents in the vicinity in the evening and during the weekends. It is a man-made lake with beautiful landscape in the middle of the city center of Shah Alam which can be divided into three sections namely the east, the west and the central. The east section is called Tasik Damai whereby the west section is called Tasik Permai. As for the middle section is called Tasik Indah. The total are for this urban park is 43 hectares with well built raised platform at certain sections of the lake for the users to enjoy the nature and water habitat surrounding the area. There are a number of facilities available includes a water theme park called Wet World Shah Alam, a floating seafood restaurant that serves Malaysian cuisine, children playgrounds, benches and kayak for rent facility. The urban park also hosts numerous events including international events such as the annual International Orchid Exhibition and the International Boat Show.

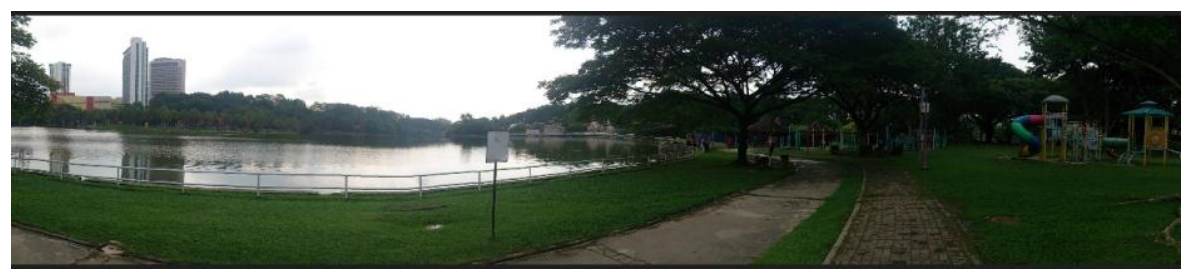

Figure 1: Panoramic view of Taman Tasik Shah Alam (Section West)

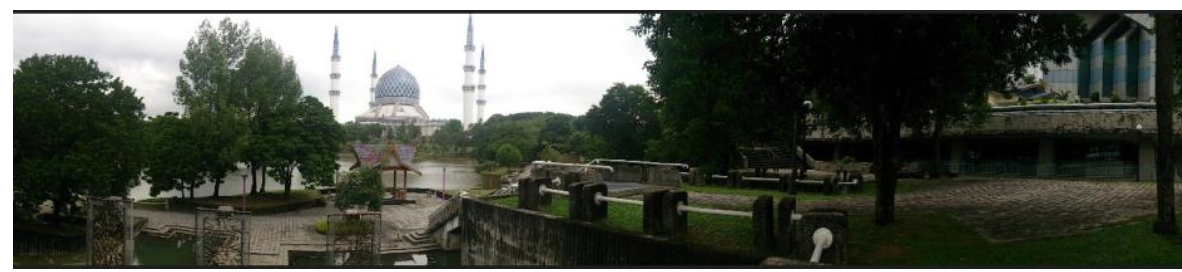

Figure 2: Panoramic view of Taman Tasik Shah Alam (Section East) 


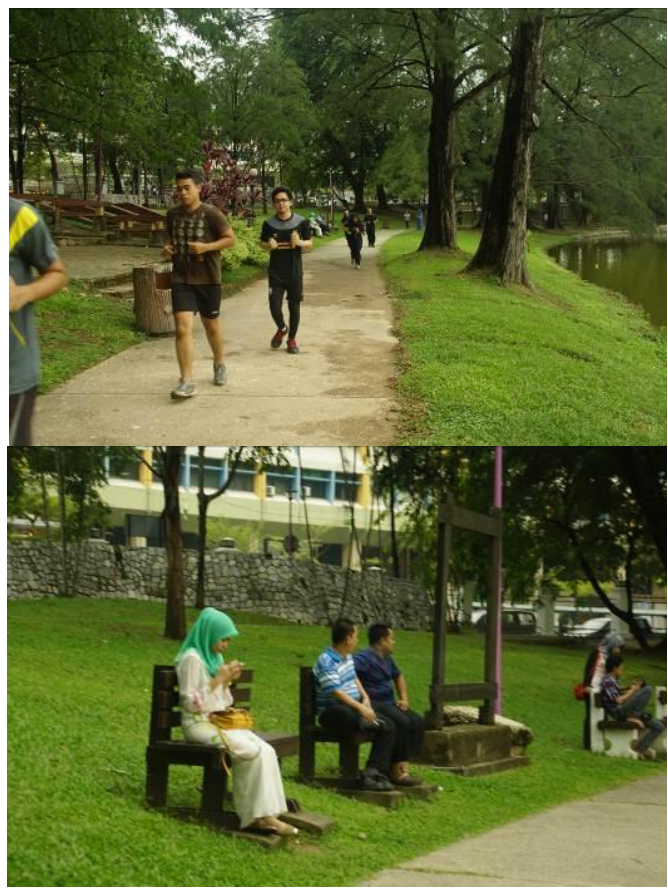

Figure 3: View of Activities and Users in Taman Tasik Shah Alam

\subsection{Results and Discussions}

The data were coded into SPSS software for descriptive statistical analysis. The main focused this analysis is to understand the relationship of human-human interactions and human-nature interactions that occurred in the open spaces area. However, additional attributes such as users' gender, race, age group, and home distance to open spaces were also considered to give additional information about the relationship. Descriptive analysis in Table 2gives a cross-tabulation overview of the number of users by gender involved in activities according to specified days.

Table 2: Descriptive Findings of Personal and Visit Information of the Respondents

\begin{tabular}{llllllc}
\hline \multirow{2}{*}{ Categories } & Variable & \multicolumn{2}{c}{ Descriptive Findings } & & & \\
& Measured & & & Gender & \multicolumn{2}{c}{ N=428 } \\
& & & Male & Female & All & $\%$ \\
\hline Personal & Age Group & 13-19 years old & 45 & 26 & 71 & 16.6 \\
Information & & $20-50$ years old & 133 & 198 & 331 & 77.3 \\
& & $50-60$ years old & 14 & 8 & 22 & 5.1 \\
\hline
\end{tabular}


Omar, D., et.al. / Asian Journal of Behavioural Studies, AjBeS, Apr / Jun 2017 (p.37-46)

\begin{tabular}{|c|c|c|c|c|c|c|}
\hline & & $\begin{array}{l}60 \text { years and } \\
\text { above }\end{array}$ & 0 & 4 & 4 & .9 \\
\hline & \multirow{3}{*}{ Marital status } & Single & 139 & 125 & 264 & 61.7 \\
\hline & & Married & 53 & 108 & 161 & 37.6 \\
\hline & & Divorce & 0 & 2 & 2 & .5 \\
\hline & \multirow[t]{2}{*}{ Nearby } & Yes & 103 & 77 & 180 & 42.1 \\
\hline & & No & 89 & 159 & 248 & 57.9 \\
\hline & \multirow[t]{4}{*}{ Come from } & Home & 116 & 156 & 272 & 63.6 \\
\hline & & College or school & 61 & 51 & 112 & 26.2 \\
\hline & & Office & 8 & 15 & 23 & 5.4 \\
\hline & & Others & 7 & 14 & 21 & 4.9 \\
\hline & \multirow[t]{4}{*}{ Range } & Less than $1 \mathrm{~km}$ & 29 & 14 & 43 & 10 \\
\hline & & $1 \mathrm{~km}-2 \mathrm{~km}$ & 26 & 74 & 100 & 23.4 \\
\hline & & $2 \mathrm{~km}-5 \mathrm{~km}$ & 81 & 52 & 133 & 31.1 \\
\hline & & More than $5 \mathrm{~km}$ & 56 & 96 & 152 & 35.5 \\
\hline & \multirow[t]{4}{*}{ Job } & Government & 24 & 50 & 74 & 17.3 \\
\hline & & Private & 38 & 63 & 101 & 23.6 \\
\hline & & Student & 120 & 102 & 222 & 51.9 \\
\hline & & Others & 10 & 21 & 31 & 7.2 \\
\hline & \multirow[t]{4}{*}{ Race } & Malay & 173 & 223 & 396 & 92.5 \\
\hline & & Chinese & 9 & 4 & 13 & 3.0 \\
\hline & & Indian & 10 & 7 & 17 & 4.0 \\
\hline & & Others & 0 & 2 & 2 & .5 \\
\hline \multirow{23}{*}{$\begin{array}{l}\text { Visit } \\
\text { Information }\end{array}$} & \multirow[t]{5}{*}{ Frequency of visits } & First time & 18 & 25 & 43 & 10 \\
\hline & & Once a week & 72 & 145 & 217 & 50.7 \\
\hline & & Twice a week & 57 & 43 & 100 & 23.4 \\
\hline & & $\begin{array}{l}\text { Three times a } \\
\text { week }\end{array}$ & 14 & 5 & 19 & 4.4 \\
\hline & & $\begin{array}{l}\text { More than three } \\
\text { times }\end{array}$ & 31 & 18 & 49 & 11.4 \\
\hline & \multirow[t]{3}{*}{ Day of visits } & Weekend & 121 & 160 & 281 & 65.7 \\
\hline & & Weekdays & 14 & 24 & 38 & 8.9 \\
\hline & & Both & 57 & 51 & 108 & 25.2 \\
\hline & \multirow[t]{4}{*}{ Time of visits } & Morning & 36 & 16 & 52 & 12.1 \\
\hline & & Evening & 148 & 214 & 362 & 84.6 \\
\hline & & Afternoon & 2 & 0 & 2 & .5 \\
\hline & & Night & 5 & 6 & 11 & 2.6 \\
\hline & \multirow{4}{*}{ Time spends } & $5-10$ minutes & 8 & 7 & 15 & 3.5 \\
\hline & & $10-30$ minutes & 101 & 109 & 210 & 49.1 \\
\hline & & 30 minutes-1hour & 59 & 93 & 152 & 35.5 \\
\hline & & More than 1 hour & 24 & 27 & 51 & 11.9 \\
\hline & \multirow[t]{5}{*}{ Transportation } & On foot & 54 & 68 & 122 & 28.5 \\
\hline & & $\begin{array}{l}\text { Public } \\
\text { transportation }\end{array}$ & 5 & 14 & 19 & 4.4 \\
\hline & & Motorcycle & 72 & 14 & 86 & 20.1 \\
\hline & & Car & 61 & 140 & 201 & 47.0 \\
\hline & & Others & 0 & 0 & 0 & 0 \\
\hline & \multirow[t]{2}{*}{ Companionship } & Alone & 44 & 29 & 73 & 17.1 \\
\hline & & $\begin{array}{l}\text { With partner or } \\
\text { friends }\end{array}$ & 114 & 124 & 238 & 55.6 \\
\hline
\end{tabular}




\begin{tabular}{lllll}
$\begin{array}{l}\text { With family } \\
\text { members }\end{array}$ & 33 & 79 & 112 & 26.2 \\
\hline
\end{tabular}

\subsection{Purpose of Using Open Spaces}

In the survey, the respondents were asked about their purpose of using the open spaces. The questions are divided into two major themes that are human-nature interaction and human-human interaction. The subthemes under human-nature interactions are; contact with nature, aesthetic preference, and recreational purposes. As for the human-human interaction subthemes, it includes social interaction and privacy, citizen participation, and community events. The result can be seen in Table 3.

Table 3: Overall Percentage of Respondents' Purposes to Taman Tasik Shah Alam Human-Nature Interaction

Human-Human Interaction

Contact with Aesthetic

Recreational
Purposes

Social

Citizen Community

Yes nature Preference Interaction Participation Events

Yes 274

64.0

90

305

193

34

39

No

154

21.0

71.3

45.1

7.9

9.1

Percentage $\quad 36.0$

338

123

235

394

389

Total

428

79.0

28.7

54.9

92.1

90.9

Total

Percentage

100

428

428

428

428

428

100

100

100

100

100

Thus, in Table 3, it can be seen that the highest percentage of respondents coming to Taman Tasik Shah Alam is for the recreational purposes (71.3\%) with the total number of 305 people. It is followed by contact with nature (64\%) with the total number of 274 respondents, social interaction (45.1\%) with total respondents of 193 , aesthetic preference $(21 \%)$ with 90 respondents, community events $(9.1 \%)$ with 39 respondents and lastly, citizen participation $(7.9 \%)$ with the total number of respondents 34 .

\subsection{Satisfaction Level of Interactions in Relation to Open Spaces}

The respondents were asked to rate their level of satisfaction with the human-nature interaction and human-human interaction. The subthemes were then divided into several topics such as the design of the open spaces, the natural and physical elements of the open spaces, the ability to pursue the interaction required, the sense of calmness and happiness in the open spaces, the appreciation of the open spaces towards the level of interactions and the overall satisfaction level of interactions that respondents experienced in the open spaces. Table 4 shows a summary of overall satisfaction level of respondents. 
Omar, D., et.al. / Asian Journal of Behavioural Studies, AjBeS, Apr / Jun 2017 (p.37-46)

Table 4: Overall Satisfactory Level of Interactions by Respondents Human-Nature Interaction Human-Human Interaction Contact Aesthetic Recreation/ Social with Nature Preference Play

Frequency

\begin{tabular}{|c|c|c|c|c|c|c|c|c|c|c|c|c|}
\hline $\begin{array}{l}\text { (n) } \\
\text { Percentage }\end{array}$ & (n) & $\%$ & (n) & $\%$ & (n) & $\%$ & (n) & $\%$ & (n) & $\%$ & (n) & $\%$ \\
\hline Not Available & 7 & 1.6 & 10 & 2.3 & 4 & .9 & 5 & 1.2 & 5 & 1.2 & 3 & .7 \\
\hline $\begin{array}{l}\text { Strongly } \\
\text { Disagree }\end{array}$ & 1 & .2 & 5 & 1.2 & 5 & 1.2 & 5 & 1.2 & 4 & .9 & 6 & 1.4 \\
\hline Disagree & 11 & 2.6 & 5 & 1.2 & 7 & 1.6 & 10 & 2.3 & 22 & 5.1 & 41 & 9.6 \\
\hline Moderate & 137 & 32.0 & 129 & 30.1 & 118 & 27.6 & 168 & 39.3 & 206 & 48.1 & 198 & 46.3 \\
\hline Agree & 217 & 50.7 & 234 & 54.7 & 247 & 57.7 & 182 & 42.5 & 145 & 33.9 & 142 & 33.2 \\
\hline $\begin{array}{l}\text { Strongly } \\
\text { agree }\end{array}$ & 55 & 12.9 & 45 & 10.5 & 47 & 11.0 & 58 & 13.6 & 46 & 10.7 & 38 & 8.9 \\
\hline Total & 428 & 100 & 428 & 100 & 428 & 100 & 428 & 100 & 428 & 100 & 428 & 100 \\
\hline Mean & 3.68 & & 3.65 & & 3.72 & & 3.61 & & 3.44 & & 3.36 & \\
\hline
\end{tabular}

Table 4 shows the overall satisfactory level of interactions by respondents can be seen as at the satisfied level. The highest satisfactory levels is for recreational and play with the total mean of 3.7290 , whereby followed with contact with nature (3.6846), aesthetic preference (3.6519), social interaction and privacy (3.6145), citizen participation (3.4486) and lastly sense of community with the total mean of 3.3645 .

\subsection{Perceived Benefits of Interactions in Open Spaces}

In this section, the respondents were asked to rate their level of perceived benefits and opinion toward Taman Tasik Shah Alam. The respondents are rated through their level of unity with nature, the unity with themselves, and sense of freedom, recreational satisfaction, adventure, and happiness. The respondent was also asked on the vitality of open spaces as part of the city sustainability. Table 5 shows the satisfactory level of perceived benefits by respondents.

In Table 5, the respondents were asked for their perceived benefits of open spaces to their daily activities. Majority of the respondents agreed that the open spaces can bring them happiness with the total mean of 3.7290. They also agreed that the open spaces provide them a sense of freedom with the total mean score of 3.6682. It is followed by the needs of recreational satisfaction (3.5514), unity with self (3.5304), unity with nature (3.4626) and lastly the sense of adventure (3.3154). The respondents were also asked the question on the vitality of open spaces as part of the city sustainability, and they respond with the highest score of mean 3.8341 . 
Table 5: Satisfactory Level of Perceived Benefits by Respondents

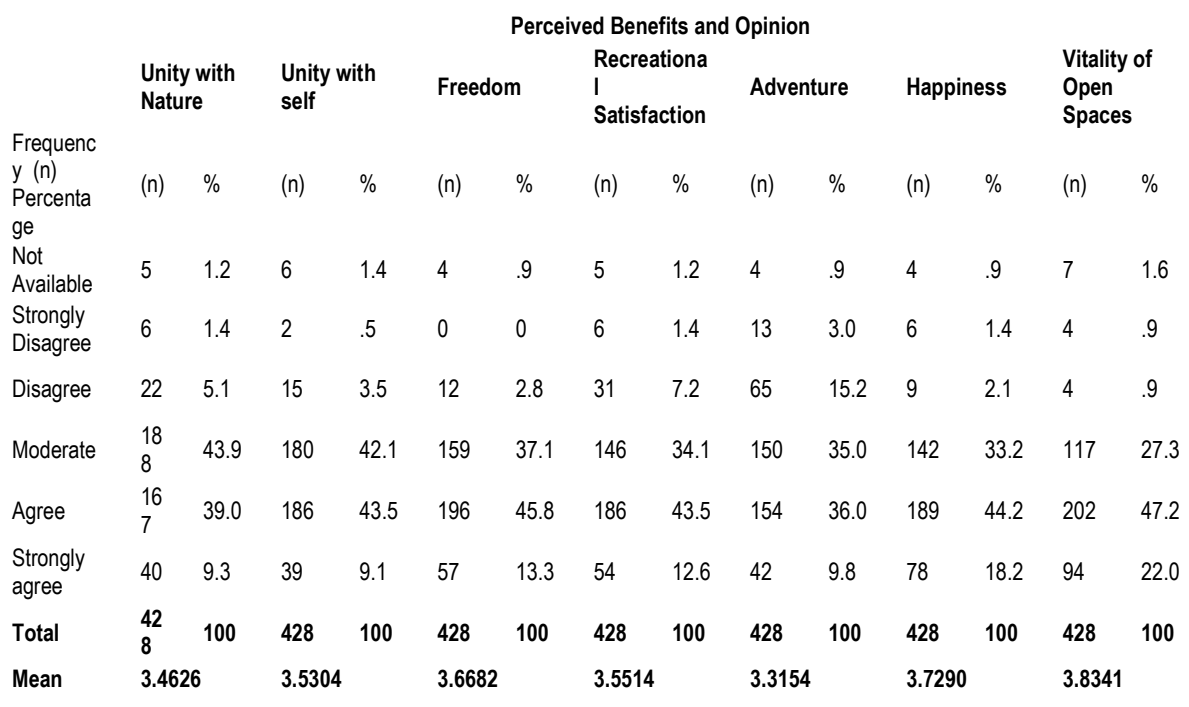

\subsection{Conclusion}

In conclusion, this study has shown that the open space is vital to the city sustainability. Human interactions are important in relation to the open spaces as both elements respond well to each other. The interactions not only benefited the human but at the same time positively effects natural ecosystem as both elements correlate with each other. This study also has shown that the nature and human interactions needs elements of open spaces such as the green spaces, water elements, physical attributes to enhance the interactions between human-human and human-nature.

Hence, further recommendations are recommended for ensuring the city sustainability especially in terms of human-nature and human-human interaction.As for human-nature interactions, among the aspect such as ecological and biological diversity should be taken into consideration as forest has lost its identity due to development of new cities. For human-human interaction, a lot of aspects for further recommendation of the study can be enhanced in terms of psychological benefits and human wellness.

\section{Acknowledgement}

The authors would like to thank all officers of Research Management Institute of Universiti Teknologi MARA particularly whom in charge for this research grant. This research is 
funded by Fundamental Research Grant Scheme (FRGS) from Ministry of Higher Education, Malaysia.

\section{References}

Chiesura, A. (2004). The role of urban parks for the sustainable city. Landscape and Urban Planning, 68(1), 129138. doi:10.1016/j.landurbplan.2003.08.003

Department of Town and Country Planning, Selangor (2004). National Physical Plan. Ministry of Housing and Local Government Malaysia, Malaysia

Marzukhi, M. A., Karim, H. A., \& Latfi, M. F. (2012). Evaluating the Shah Alam City Council Policy and Guidelines on the Hierarchy of Neighborhood Open Space. Procedia - Social and Behavioral Sciences, 36(June 2011), 456465. doi:10.1016/j.sbspro.2012.03.050

Matsuoka, R. H., \& Kaplan, R. (2008). People needs in the urban landscape : Analysis of Landscape And Urban Planning contributions, 84, 7-19. doi:10.1016/j.landurbplan.2007.09.009

Mutiara, S., \& Isami, K. (2012). Characteristic of Public Small Park Usage in Asia Pacific Countries : Case Study in Jakarta and Yokohama City, 35(December 2011), 412-419. doi:10.1016/j.sbspro.2012.02.106

Philips, L.E., (1996). Parks: design and management,United States of America: McGrawHill.

Rasidi, M. H., Jamirsah, N., \& Said, I. (2012). Urban Green Space Design Affects Urban Residents' Social Interaction. Procedia - Social and Behavioral Sciences, 68(November), 464-480. doi:10.1016/j.sbspro.2012.12.242

Shuib, K.B., (2008). Context, concept and purpose of park and protected areas, Shah Alam: Recreational Park Planning. 